\title{
Age and growth analysis of the fish Mastacembelus armatus (Lacepede) from River Nayar, Garhwal Himalaya, Uttarakhand
}

\section{Mohd Rashid}

Aquatic Biodiversity Laboratory, Department of Zoology, B.G.R Campus, HNB Garhwal University, Pauri-Garhwal (Uttarakhand), India

\section{Mohd Sagir*}

Aquatic Biodiversity Laboratory, Department of Zoology, B.G.R Campus, HNB Garhwal University, Pauri-Garhwal (Uttarakhand), India

\section{A. K. Dobriyal}

Aquatic Biodiversity Laboratory, Department of Zoology, B.G.R Campus, HNB Garhwal University, Pauri-Garhwal (Uttarakhand), India

*Corresponding author. Email: mohdsagir13@gmail.com

\section{Article Info}

https://doi.org/10.31018/ jans.v13i1.2478

Received: January 1, 2021

Revised: February 12, 2021

Accepted: February 18, 2021

\section{How to Cite}

Rashid, M. et al. (2021). Age and growth analysis of the fish Mastacembelus armatus (Lacepede) from River Nayar, Garhwal Himalaya, Uttarakhand. Journal of Applied and Natural Science, 13(1): 137 - 144. https://doi.org/10.31018/jans.v13i1.2478

\begin{abstract}
The ability to age fish accurately is essential in understanding the dynamics of fish population. Age and growth determination in Mastacembelus armatus was assessed by the scale method which was verified by the length-frequency distribution method. The scales were small, elongated and the focus was shifted slightly uppish from the centre. The fish length and scale radius relationship was found linear (Scale radius $=6.974+0.452$ Fish length; $r=0.9746$ ) and authenticated the age analysis. Back calculation method was used to find out the size of fish at annulus formation, which confirmed four age rings in $M$. armatus at the size of $14.07 \pm 0.92,26.05 \pm 4.99,37.96 \pm 2.59$ and $48.48 \pm 6.06 \mathrm{~cm}$ respectively. First two age rings were observed in the fish length group $30-40 \mathrm{~cm}$, the third ring was observed in $40-50 \mathrm{~cm}$ and the fourth ring in $50-60 \mathrm{~cm}$ length group. The finding was dully validated by length-frequency distribution method. The growth annual increment $(\mathrm{h})$ of $M$. armatus shows that the length increment was $14.07,13.32,11.91$ and $10.52 \mathrm{~cm}$ during $1^{\text {st }}, 2^{\text {nd }}, 3^{\text {rd }}$ and $4^{\text {th }}$ year respectively. It shows that the fish grows continuously during its entire life period. The average growth $(\varphi \mathrm{h})$ was observed as $12.12 \mathrm{~cm}$. annually. The assessment of age and growth rate of fish is a prerequisite to generate the information on recruitment, longevity and fluctuations in fishery caused by various year classes which is an important tool for rational exploitation of fish stock.
\end{abstract}

Keywords: Age and Growth, Scale, Length Frequency, Mastacembelus armatus, Nayar

\section{INTRODUCTION}

Investigations on the basic biological features of the fish in its natural habitat help in its conservation and management in controlled aquaculture system. It includes knowledge of maturation process, spawning season and frequency, reproductive capacity, food preference and feeding behaviour and age, growth pattern, size and age at first maturity, etc. Apart from this population dynamics study also helps in validation of age in fishes after mathematical calculations from scales, vertebrae, otolith and other suitable hard structures (Bahuguna and Dobriyal (2019).

The accuracy in age determination depends upon proper identification of age rings scientifically verified through either known age method or by the lengthfrequency distribution method. Under intensive culture, it is possible to have an idea of known age, but in wild nature, it is bit difficult, but for species which breed once a year it becomes easy due to the clustering of fish of the same size around a particular fish length. According to Francis (1990), an accurate and reliable technique to age fish is an essential requirement for assessing the health of a population.

Age determination of fish from the hard skeletal structures (scales, otoliths, vertebra, fin spines, fin rays, etc.) is a matter of routine with most exploited fish stocks. Peterson (1892) proposed a simple but significant method of age determination by length-frequency distribution. Scales, otoliths, vertebrae, operculum and 
fin spine are the most common methods employed these days for ageing. According to Oliveria (1996) and Neilson et al., (2003), the direct observational method which accounts capturing, releasing and recapturing the fish in a controlled environment is also a valid method for ageing the fish.

However, counting annual rings is open to many uncertainties (Dobriyal and Singh, 1990). Important contributors to the study of age and growth rate of fish during recent years are Johal and Tondon (1987, 1992), Dobriyal (1988), Vasudevappa and James (1988), Dobriyal and Singh (1990), Johal and Kingra (1992), Tandon et al. (1993), Tandon and Johal (1996), Bisht et al., (1996), Rawat and Nautiyal (1996), Johal et al. (2000), Dobriyal and Negi (2001), Dobriyal et al. (2004), Uniyal et al., (2005), Pathani and Joshi (2006), Bahuguna and Balodi (2015) and Singh et al. (2017). The present study was aimed to explore the longevity and size of fish at different ages in a very important fish species Mastacembelus armatus. This information will be very helpful in its conservation and management.

\section{MATERIALS AND METHODS}

\section{Study area}

The Nayar Basin lies in Pauri Garhwal district of Uttarakhand Himalaya bounded by Tehri in North, Chamoli in East, Almora in South East, Nanital in south and Dehradun in West. The Nayar basin is unique in its features like horn peaks, serrated creats hanging valleys, torrential rapids and waterfalls. In the central Himalayas most of the rivers are fed by snowmelt, (Yamana, Bhagirathi, Alaknanda, Pinder, Dhauli, Ganga, Mandakinietc), while the river like Ramganaga, Kosi and Nayar are exclusively spring -feed Rivers.

The River Nayar exploited for present study originates from the Dhoodhatoli Mountain at the elevations 3116 masl. The DhoodhatoliKhatil - anticline divides the basin of the Eastern Nayar and Western Nayar which make the confluence at NaugaunKamand near Satpuli at 620 masl. After confluence, the river enters in a gorge from Marora to Vyasghat, where it finally confluences with the river Ganga at 447 masl (Fig. 1). The western Nayar valley presents a unique set of ecological characteristics over a complex variety of systems that incorporate forests, meadows, grasslands, marshes and rivers, as well as wildlife, geology and several other Phyto-geographically distinctive peculiarities. The occurrence of diverse topographical and climatic factors has resulted in the remarkable biodiversity of the river as a result of which flora also correspondingly differs over its different parts. The authors were granted permission to work on the biology of this particular species by the Department of Forest, Govt of Uttarakhand. Thus, there is no issue of Animal ethics.

\section{Methodology}

Scale method was used for age determination in $M$. armatus, which was validated by the method of lengthfrequency distribution. For length frequency distribution, the fish were arranged in different length groups, season-wise and finally an assessment was made based on the facts that the fish of same year classes formed a bunching at a proper length group (Peterson, 1892). The reason for taking season-wise data was due to the fact that viewing the population dynamics of this particular species only limited numbers of specimens were captured.

\section{Scale method}

About ten to fifteen scales were taken from below the dorsal fin in each selected specimen, cleaned and stored. Out of these, the common five scales of each fish were later selected and further cleared in $1 \% \mathrm{KOH}$ solution. The fish length and scale radius relationship was traced out to know whether there was a constant increment in growth or not. It was traced out with the help of regression analysis, viz.

$\mathrm{Y}=\mathrm{a}+\mathrm{bx}$ .Eq.1

Where:

$X=$ fish length (an independent variable)

$Y=$ scale radius ( $a$ dependent variable), $a$ and $b=$ constants (intercept and slope)

Growth rings were very carefully identified as in many occasion, false rings were also observed (Tandon and Johal, 1996). The period of growth ring formation was recorded as the highest percentage of the minimum width in the terminal zone of the scales. Based on the time between the formations of two rings, the frequency was assessed and the age was estimated. Length frequency distribution for different seasons was obtained by arranging the data at $10 \mathrm{~cm}$ class intervals and recording the mode indicative of different age groups.

\section{Back calculation for scale}

The growth rate of fish was calculated by backcalculation method as suggested by Lea (1910). The formulae read as:

$\mathrm{In}=\mathrm{Sn} / \mathrm{SR} \quad \mathrm{xI}$

where $-\ln =$ length of fish when annulus $n$ formed,

$\mathrm{S} n=$ scale radius of annulus $\mathrm{n}$ at $\mathrm{In}$

I= length of fish when a scale sample was obtained,

$\mathrm{SR}=$ Scale radius

The growth parameters of $M$. armatus were calculated as suggested by Tandon and Johal (1996) as follows:

\section{Specific rate of linear growth:}

$$
\mathrm{Cl}=\mathrm{In}-\mathrm{In}-1 / \mathrm{In}-1 \times 100
$$

Index of species average size:

$$
\begin{gathered}
\varphi \mathrm{h}=\mathrm{a} \mathrm{nj}+\mathrm{a} \mathrm{h} \\
\mathrm{h}=\mathrm{l} / \mathrm{nj}+\mathrm{a}
\end{gathered}
$$

\section{Growth characteristics:}

Cth=log In - log In-1 / $0.4343 \times$ In-1 Eq.5 


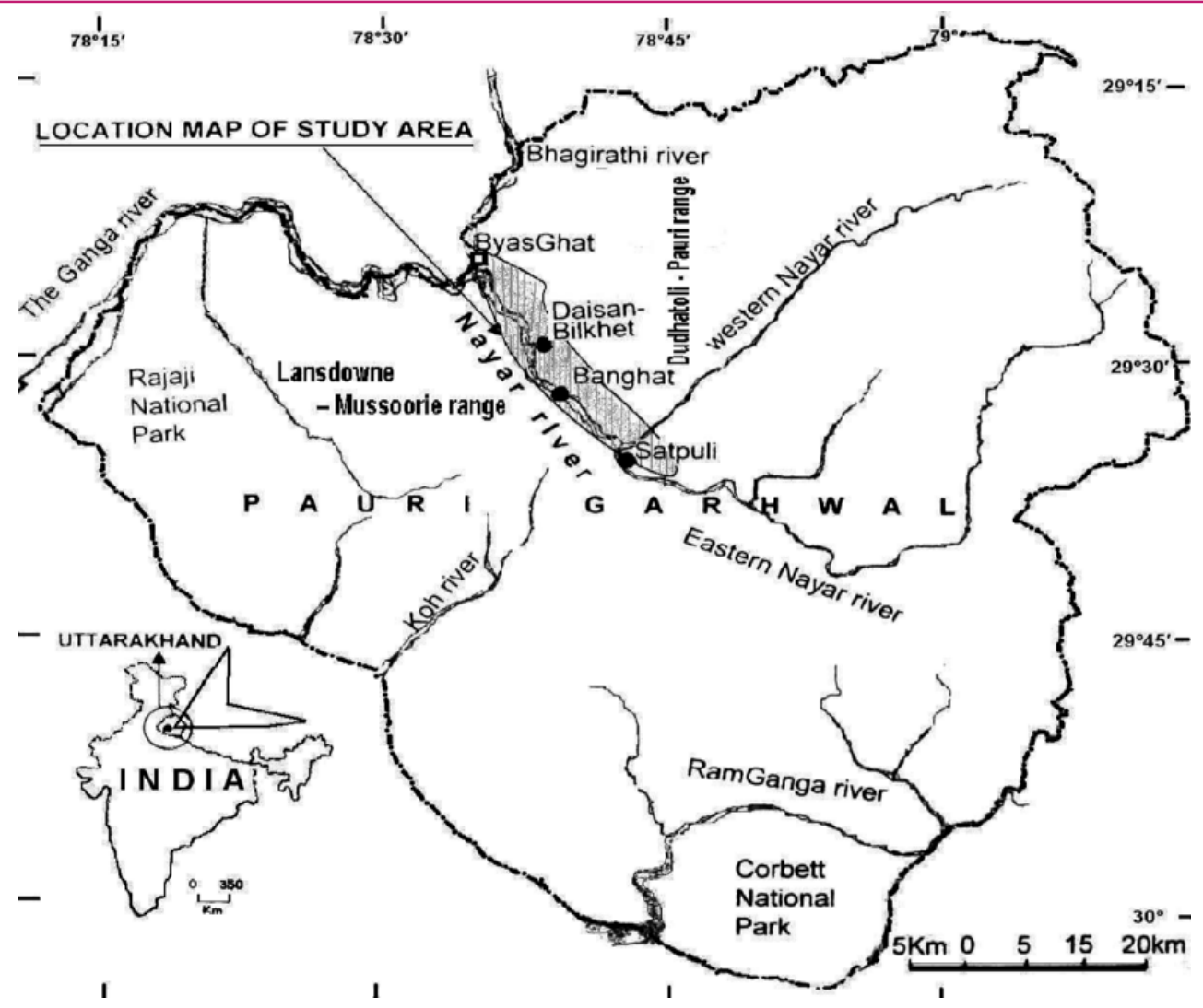

Fig. 1. Map of Pauri- Garhwal (Uttarakhand) showing drainage of river Nayar along with its parent streams, the WestrenNayar and the Eastern Nayar.

\section{Growth constant}

Clt $=\log$ In $-\log \ln -1 / 0.4343 \times \mathrm{t} 2+\mathrm{t} 1 / 2$

.......Eq.6

Where In and In -1 are mean computed total length of fish at ultimate and penultimate year of life.

$\mathrm{J}=$ Juvenile, $\mathrm{a}=$ adults, $\mathrm{n}=$ number, $\mathrm{h}=$ absolute increment in length, $\mathrm{t} 2+\mathrm{t} 1$ are the time intervals between - ultimate and penultimate age classes and the value of $\mathrm{t} 2+\mathrm{t} 1 / 2$ is equal to 1.5

\section{RESULTS}

The present study observed that the scales of $M$. armatus were quite small with a maximum size of $2.1 \mathrm{~mm}$ and were elongated anterio- posteriorly. The Focus was shifted towards the anterior side with fewer margins in comparison to its lateral side. Rings were clearly identified as breaking and widening in circuli. On some occasions, false ring was also observed, but it was distinct being not in a uniform manner.

Fish length and scale radius was found linear (Fig 2) and authenticated the age analysis. The relationship can be expressed as:

Scale radius $=6.974+0.452$ Fish length $(r=0.9746$, $\left.r^{2}=0.95\right)$

For age calculation, scale radius was measured along with the distance of each ring from the focus. This data is presented in Table 1. It showed that no ring was observed in fishes with length group $20-30 \mathrm{~cm}$. Fish below the size of $20 \mathrm{~cm}$ could not be noticed. Two age rings were noticed in the fish ranging between $30-40 \mathrm{~cm}$, however, three age rings were noticed in the fish measuring from $40-50 \mathrm{~cm}$. Maximum four rings were recorded in the fish ranging from $50-60 \mathrm{~cm}$ (Fig. 3-6)

The data observed at which fish length the rings were formed estimated by back calculation method is presented in Table 2.

It was observed that the average fish length at the time of $1^{\text {st }}, 2^{\text {nd }}, 3^{\text {rd }}$ and $4^{\text {th }}$ ring was $14.07 \pm 0.92,26.05$ $\pm 4.99,37.96 \pm 2.59$ and $48.48 \pm 6.06 \mathrm{~cm}$ respectively.

The season and reason of ring formation was assessed by the analysis of minimum width in ring and

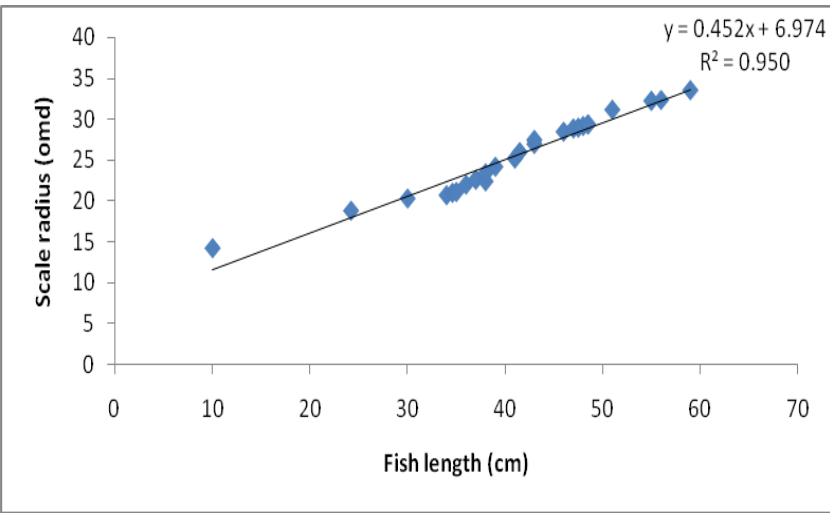

Fig. 2. Regression between fish length and scale radius in M. armatus. 


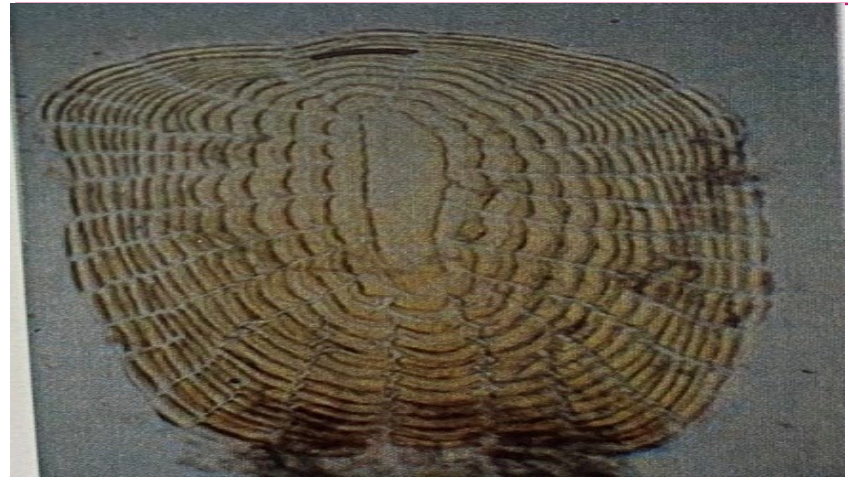

Fig. 3. Scale of fish with one annuli.

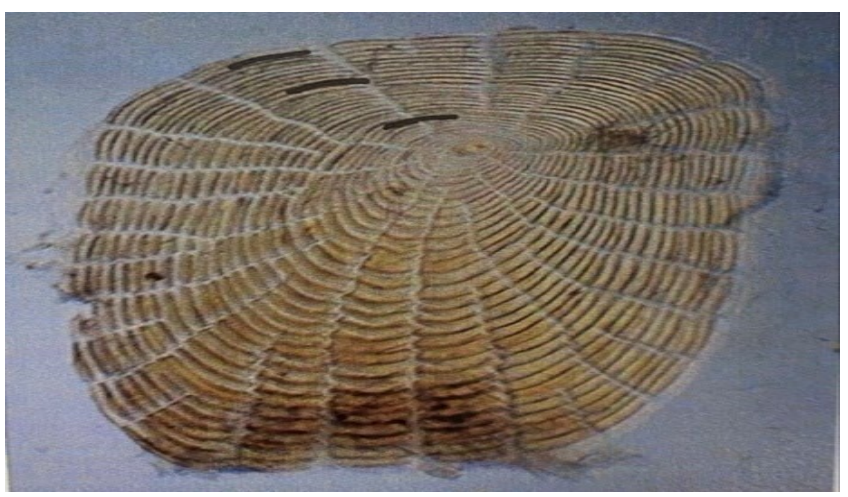

Fig. 5. Scale of fish with three annuli.

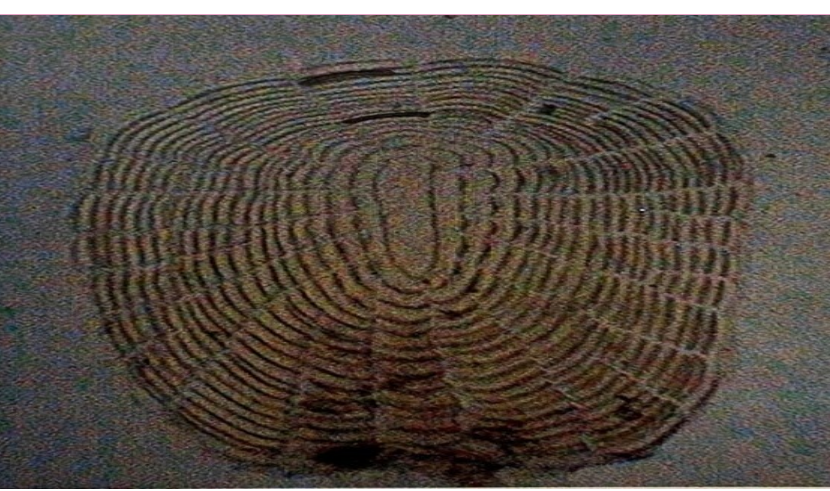

Fig.4. Scale of fish with two annuli.

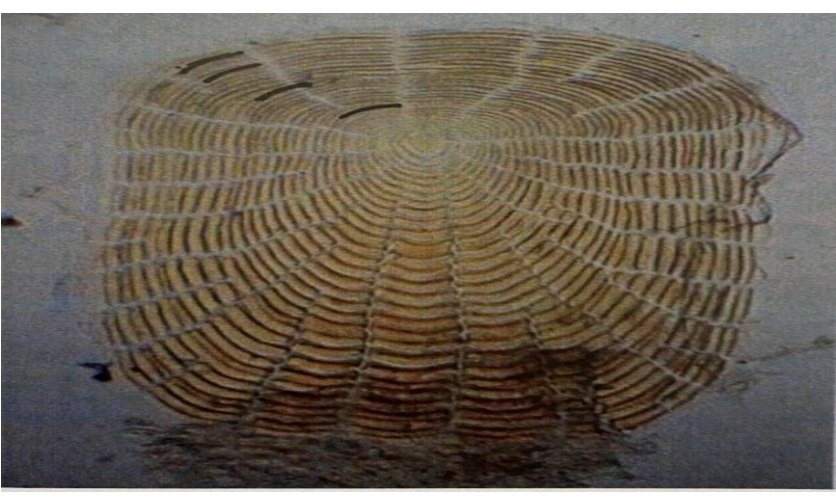

Fig.6. Scale of fish with four annuli.

Table 1. Data on the age and growth of $M$. armatus in different length groups.

\begin{tabular}{llllll}
\hline $\begin{array}{l}\text { Length Groups } \\
(\mathbf{c m})\end{array}$ & $\begin{array}{l}\text { Average Fish } \\
\text { length }(\mathbf{c m})\end{array}$ & S-1 (omd) & S-2 (omd) & S-4 (omd) & S-4 (omd) \\
\hline $20-30$ & $24 \pm 0.0$ & - & - & - & - \\
$30-40$ & $35.8 \pm 0.837$ & $7.6 \pm 2.3$ & $12.6 \pm 2.08$ & - & - \\
$40-50$ & $44.07 \pm 3.02$ & $8.57 \pm 1.62$ & $17.42 \pm 2.82$ & $24.0 \pm 4.06$ & - \\
$50-60$ & $55.0 \pm 2.83$ & $9.0 \pm 1.41$ & $22.5 \pm 0.71$ & $28.0 \pm 2.83$ & $39.5 \pm 0.71$ \\
\hline
\end{tabular}

S-1 (Scale radius when $1^{\text {st }}$ ring formed), S-2 (Scale radius when $2^{\text {nd }}$ ring formed), S-3 (Scale radius when $3^{\text {rd }}$ ring formed), S-4 (Scale radius when $4^{\text {th }}$ ring formed)

terminal zone of scale. The data presented in Fig. 7 indicated that the ring was formed during monsoon season and the probable reason being growth check due to breeding pressure and also the disturbed weather due to flash flood after rains.

Growth parameters of the fish calculated, as suggested by Tandon and Johal (1996) are presented in Table 3.

The age calculated by scale method was confirmed by the length-frequency distribution method (Peterson's methods). The length-frequency polygons are presented in Fig. 8. After micro-level examination, it was observed that the fish attained a length of $15,25,35$, and $45 \mathrm{~cm}$ during first, second, third and fourth year respectively.

\section{DISCUSSION}

The ability to age fish accurately is essential in understanding the dynamics of the fish population. It is not only a basic scientific research but also gives us an idea of its harvestable size (Tandon and Johal, 1996). In fish farms where fish are segregated yearly and stocked in year wise stocking ponds, the actual size range as per age class can be estimated, and this is called "Known age method". This method is timeconsuming and can be applied only in fish culture. However, it is used for confirmation of age calculated by

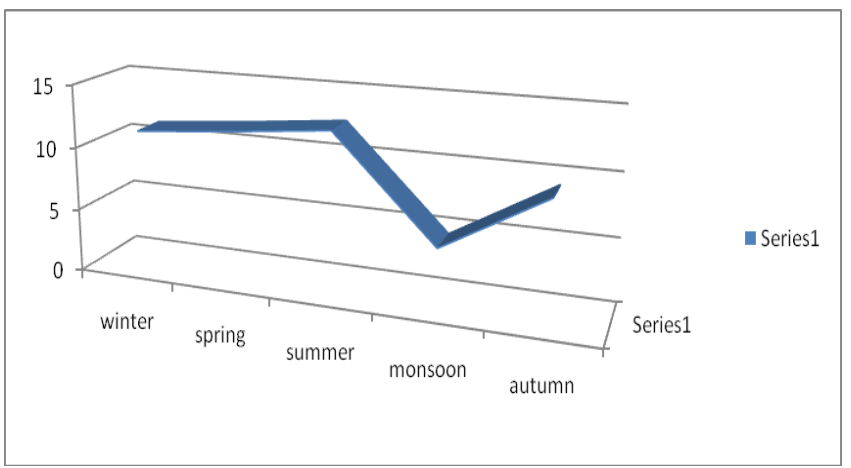

Fig. 7. Minimum width in terminal zone (omd) on scales of $M$. armatus showing seasons of ring formation. 


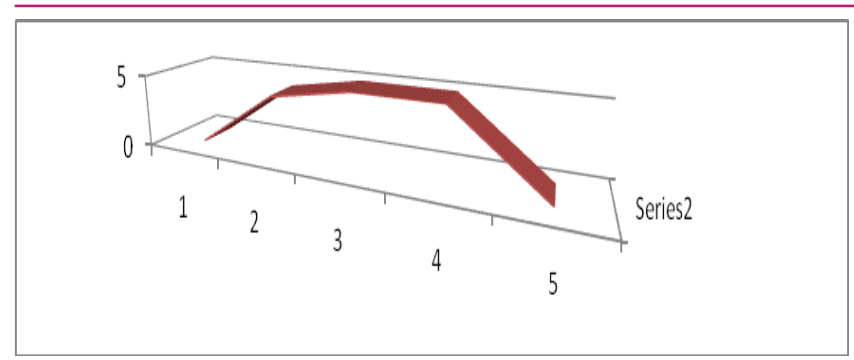

\section{Length frequency of winter season .}

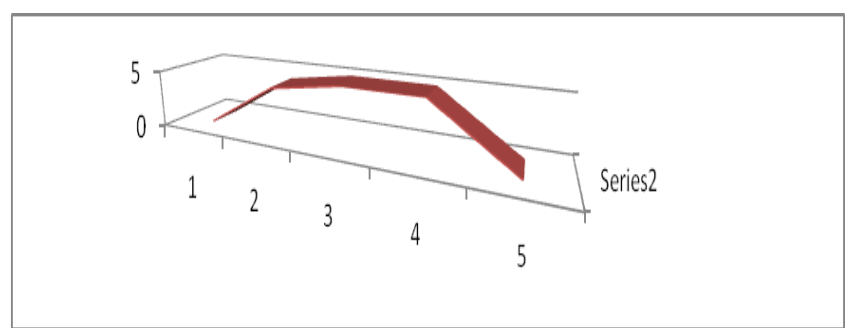

III. Length frequency of summer season.

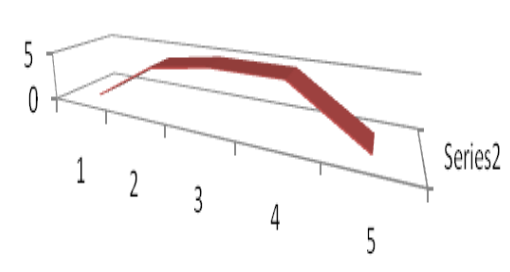

II. Length frequency of spring season.

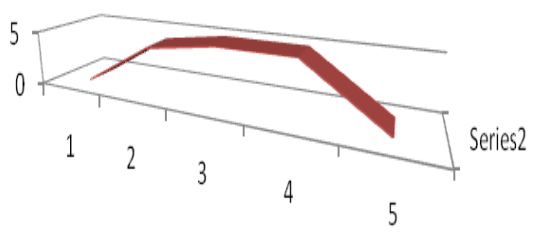

IV. Length frequency of monsoon season.

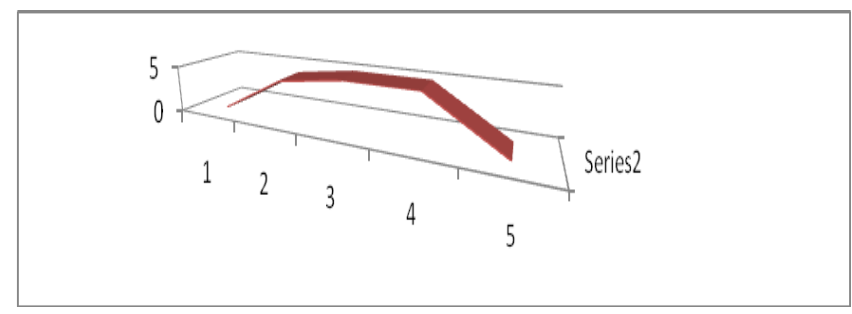

V. Length frequency of autumn season. (x axis- Average length $1-15 \mathrm{~cm}, 2-25 \mathrm{~cm}, 3-35 \mathrm{~cm}, 4-45 \mathrm{~cm}, 5-55 \mathrm{~cm}$; $Y$ axis- Number of fish)

Fig. 8. Length Frequency distribution of M. armatus showing age group congregation during different seasons in Nayar River.

Table 2. Back calculated length of $M$. armatus based on age class.

\begin{tabular}{llllll}
\hline Length Groups $(\mathbf{c m})$ & $\begin{array}{l}\text { Fish length } \\
(\mathbf{c m})\end{array}$ & L-1 (cm) & L-2 (cm) & L-3 (cm) & L-4 (cm) \\
\hline $20-30$ & - & - & - & - & - \\
$30-40$ & $35.8 \pm 0.837$ & $12.48 \pm 3.82$ & $20.4 \pm 3.5$ & - & - \\
$40-50$ & $44.07 \pm 3.02$ & $13.75 \pm 2.69$ & $27.89 \pm 4.66$ & $36.13 \pm 4.18$ & - \\
$50-60$ & $55.0 \pm 2.83$ & $15.97 \pm 2.21$ & $29.86 \pm 1.78$ & $39.8 \pm 2.99$ & $48.48 \pm 6.06$ \\
Average value & $44.96 \pm 9.63$ & $14.07 \pm 0.92$ & $26.05 \pm 4.99$ & $37.96 \pm 2.59$ & $48.48 \pm 6.06$ \\
"h" Annual increment & & 14.07 & 11.98 & 11.91 & 10.52 \\
\hline
\end{tabular}

L-1 (Fish length when $1^{\text {st }}$ ring formed), L-2 (Fish length when $2^{\text {nd }}$ ring formed), L-3 (Fish length when $3^{\text {RD }}$ ring formed), L-4 (Fish length when $4^{\mathrm{TH}}$ ring formed)

other methods. Another method of age determination is TCRC which means tagging, clipping, release and capture again (Pine et al., 2003). This method is applicable in fish capture, but it is costly and timeconsuming. Fish biologists unanimously agree that best and reliable method of ageing fish is counting annuli (growth ring) on the hard skeletal parts of fish, viz., scales, vertebrae, operculum, spines and otoliths, which are formed as a result of irregular growth and metabolism (Jhingran, 1959; Tandon and Johal, 1996; Dobriyal and Singh, 1990).

During the present investigation on $M$. armatus, the scales were observed to be small in size, slightly elongated on the anterior-posterior face and the focus was recorded to be shifted slightly uppish from the middle. Radius and annuli were distinct and breaking and widening in curculi were identified as growth rings (Figs. 3 -6). Some time few larval rings were also observed during present investigation which were neglected. These rings were termed as "Zero ring" by Tandon and Johal (1996). In the present study regression analysis was made between fish length and scale radius, which was observed to be linear and confirms the justification of age determination by this method. 
Table 3. Summary of growth parameters of M. Armatus.

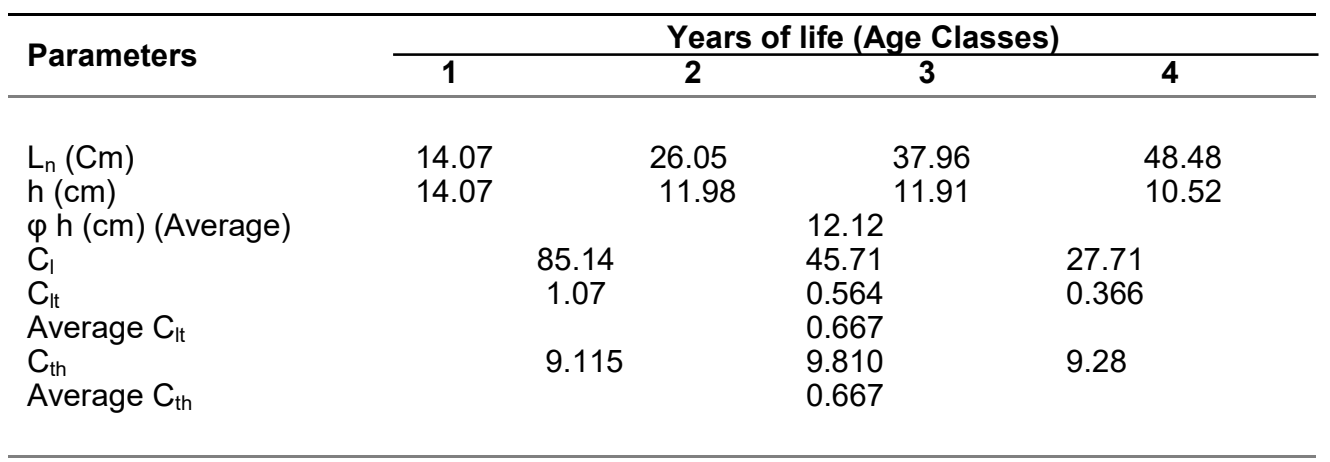

$L_{n}=$ length of fish at the time of $n$ ring formation, $h=$ length increment every year, $\varphi h=$ average length increment, $C_{l}=$ specific rate of linear growth, $C_{t t}=$ Growth constant and $C_{t h}=$ growth characteristics

Johal and Tondon (1987) while working on C. mrigala, Johal and Kingra (1992) on Catla catla, Bisht et al. (1996) on S. plagiostomus, Uniyal et al. (2005) on Tor chelynoides and Bahuguna and Dobriyal (2019) on Puntius conchonius, found a linear relationship with a high degree of correlation between total length and scale radius length.

Back calculation method used for calculation of size of fish at different age ring formation indicated that four age rings were formed in $M$. armatus at the size of $14.07 \pm 0.92,26.05 \pm 4.99,37.96 \pm 2.59$ and $48.48 \pm$ $6.06 \mathrm{~cm}$ respectively. This observation was confirmed by the method of length frequency distribution method on the basis of which the age was calculated as 15,25 , 35 , and $45 \mathrm{~cm}$ during first, second, third and fourth year respectively. Lagler et al. (1977) suggested that the length-frequency method is based on the expectancy that the frequency analysis of a species of any one age group collected on the same data will show variations around the mean length according to normal distribution. Thus, there will be clumping of fish of successive ages at successive length when sampled at randomly.

It is essential to know the time or season of ring formation and the causes responsible for it. In the present investigation, it was observed that age ring in $M$. armatus was formed during monsoon season when the ring was very close to scale terminus. This is called analysis of minimum width in the terminal zone. The reason can be assumed that firstly the ecological disturbance due to flash flood after rain reduces the availability of food in nature. Secondly this is the time when fish is gravid and filled with ova or mature testes. This physiological condition doesn't allow fish to feed. Hence stress causes growth check and annuli are formed.

Different researchers have opined their experiences on the causes of ring formation. Kesteven (1942) stated that feeding ceases for a period of breeding which may cause annulus formation in Mugil dobula. Chacko and Krishnamuraty (1950) discussed the significance of growth ring on the scale in Hilsa ilisa of Godavari and stated that there was a period of starvation concurrent with the spawning act, resulting in the ring on the scale. Seshappa and Bhimachar (1951) were of the opinion that the formation of annuli on scales in Cynoglossus semifarciatus and $M$. parsia respectively was due to the non-availability of food during the rainy season an account of disturbance of benthic fauna which forms the fish food. Pillay (1954) observed the upwelling of bottom flora from the flood caused reduce feeding in Mugil tadeand the consequent growth checks. Sarojini (1957) in M. parsia and Jhingran (1959) in Cirrhinus mrigala observed that the non-availability of food was a probable factor causing annulus formation on scales.

Several workers from India and abroad are of the opinion that the variation in temperature (Holcik, 1967) and spawning (Van Oosten, 1937; Natrajan and Jhingran,1963; Linfield, 1979; Dobriyal et al., 2004) are the important causative factor responsible for annulus formation. Kohli and Goswami (1989) while working on the pectoral spine of $H$. Fossilis, expressed that the annual ring was formed in May-June, which is the spawning period of fish in Assam. He further stated that the formation of growth rings could be attributed to the cumulative effect of "nutrition and spawning". Pathani (1981) explained the cause of ring formation in mahseer (Tor putitora) as the stress of low temperatures. Dobriyal and Singh (1990) in Barilius bendelisis also identified the growth rings as spawning marks. Bahuguna and Dobriyal (2019) who studied the age determination of Puntius conchonius also explained that spawning stress is responsible for ring formation.

The growth annual increment (h) of $M$. armatus showed that the length increment was $14.07,13.32,11.91$ and $10.52 \mathrm{~cm}$ during $1^{\text {st }}, 2^{\text {nd }}, 3^{\text {rd }}$ and $4^{\text {th }}$ year respectively. It showed that the fish grew continuously during its entire life span of $4^{+}$years. The average growth $(\varphi \mathrm{h})$ was observed as $12.12 \mathrm{~cm}$. The specific rate of linear growth (Cl), between first and second year was noticed to be 104.6, second and third year 45.71 and in between third and fourth year as 27.71. The value of growth characteristics was (Cth) observed as 9.4 on average 
with continuous growth throughout life. The growth constant $(\mathrm{Cl})$ was observed as 0.667 in an average, which was a little high in the first year (1.07) but low in coming years.

\section{Conclusion}

The present study is significant in exploring the longevity of fish and its growth pattern with increasing age. Regression analysis showing a straight line between fish size and scale radius is an indicator of constant growth in both parameters and hence validates the present study. Growing small size fish were not available in the entire course of study as field observations indicated that fish spawns deep inside under rocks and boulders during monsoon season. On the basis of scale study and its length-frequency distribution in nature, it was concluded that the fish attains a size of approximately $14 \mathrm{~cm}$ in the first year, $26 \mathrm{~cm}$ in the second year, $37 \mathrm{~cm}$ in the third year and $48 \mathrm{~cm}$ in the fourth year. The data generated in this study will be of great help for the conservation and management of this species in its natural or artificial habitat in future.

\section{Conflict of interest}

The authors declare that they have no conflict of interest.

\section{REFERENCES}

1. Bahuguna P. and Balodi V. P. (2015). Age and Growth of Puntius Conchonius (Ham.-Buch.) From Mandal River (District: Pauri Garhwal), Uttarakhand, India. Int. J Sci. Rec., 4 (6), 167- 170.

2. Bahuguna, p. and Dobriyal, A.K. (2019). Biology of the Ornamental Fish Puntius conchonius (Ham.-Buch.). Narendra Publishing House. New Delhi p.236

3. Bisht, K.L., Singh, H.R. and Chopra, A.K. (1996). A study on the age and growth of Schizothoraxplagiostomus (Heckel) of river Pinder in Garhwal Himalaya. Him. J. Env. Zool. 10: 87-91.

4. Chacko, P.I. and Kirshanamurti, B. (1950) A biometrical study of Hilsa ilisha (Ham.) in the Godavari River. J. Bombay Nat. Hist. Soc. 49: 315-316

5. Dobriyal, A. K. and Singh, H. R. (1990). Ecological studies on the age and growth of Barilius bendelisis (Ham.) from India. Archiv. Fur Hydrobiologie. Stuttgart, 118(1), 93-103.

6. Dobriyal, A.K. (1988). Otolith as an indicator of age in the carp Barilius bendelisis (Ham). Agri. Biol. Res. 4, 67-69

7. Dobriyal, A.K. and Negi, K.S. (2001). Age growth and Harvestable size of a coldwater fish Crossocheilus latius latius (Ham.) from India. Ad. Bios. 20(1), 1-18

8. Dobriyal, A.K., Thapliyal, A., Joshi, H.K., Uniyal, S.P., and Bahuguna, P. (2004). Trunk vertebrae as an instrument for the determination of age and growth rate of Pseudecheneis sulcatus (Pisces: Sisoridae). J. Natcon. 16 (2), 439-446.

9. Francis, R.I.C.C. (1990). Back-Calculation of fish length: a critical review. J. Fish Biol., 36: 883-902 https:// doi.org/10.1111/j.1095-8649.1990.tb05636.x

10. Holcik, J. (1967). Life history of the roach Rutilus rutilus L. in the Klicava reservoir. Vestnik Ceskoslovenske Spole Cnosti Zoologicke, 31, 213-229

11. Jhingran, V. G. (1959). Studies on the age and growth of Cirrhinusmrigala (Ham.) from the river Ganga. In Proc. Nat. Inst. Sci. India, 25 (3), 107-139

12. Johal M. S., Kingra J.S. (1992). Growth parameters of Catlacatla(Hamilton). Him. J. Env. Zool. 6, 1-6.

13. Johal, M. S. and K. K. Tandon (1987). Harvestable size of two indian major carps. Vest. Cs. Spolec. Zool., 51, 177182

14. Johal, M. S. and Tandon, K. K. (1992). Age and growth of the carp Catlacatla (Hamilton 1822) from Northern India. Fisheries Research, 14(1), 83-90

15. Kesteven, G. L. (1942). Studies on the biology of the Australian mullet. Part I. Account of the fishery and preliminary statement of the biology of Mugil dobula Gunther. Coun. Sci. Industr. Res. Bull. Melbourne 157.

16. Kohli, M. S. and Goswami, U. C. (1989). Studies on age and growth of an air breathing cat fish Heteropneustes fossilis(Bloch). J. Inland Fish Soc. India, 21(2), 17-24.

17. Lagler, K. F., Bardach, J E, Miller, R. R. and Passino, D. R. M. (1977). Ichthyology, Wiley, NewYork.

18. Lea, E. (1910). On the methods used in the Hering investigations, Publ. Circonst. Cons. Perm. Int. Explor. Mer. 108, 14-22.

19. Linfield, R. S. J. (1979). Age determination and year class structure in a stunted roach, Rutilus rutilus population. Journal of Fish Biology, 14(1), 73-87.

20. Natrajan, A. V. and Jhingran, A. G. (1963). On the biology of Catla catla (Ham.) from the river Yamuna. In Proc. Natl. Inst. Sci. India B (Vol. 29, pp. 326-355).

21. Neilson, J. D., Stobo, W. T. and Perley, P. (2003). Age and growth of Canadian east coast pollock: comparison of results from otolith examination and mark-recapture studies. Transactions of the American Fisheries Society, 132(3), 536-545; https://doi.org/10.1577/15488659(2003)132<0536:AAG OCE>2.0.CO;2

22. Oliveria, K. (1996). Field validation of annular growth rings in the Americal eel Anguilla rostrata, using tetracycline marked otoloths. US National marine Fisheries Service, Fishery Bulletin, 94:186-189.

23. Pathani, S. S. (1981). Age and growth of mahseer, Tor putitora (Ham.) as determined by the scales and operculum. Matsya, 7, 41-46.

24. Pathani, S.S. and Joshi, R.K. (2006). Age and growth of the hillstream fish Botia almorhae (Gray) by scales, operculum and centrum of vertebra. Aquacult. 7 (2), 199-209.

25. Peterson, C. G. J. (1892). Fiskensbiologiske forhold iHolbock Fjord, 1S9Q.91-Bermingfra de Danake Biologiske Station for 1890 (91), 121-183.

26. 26. Pillay, T. V. R. (1954). The biology of the grey mullet Mugil tadeForskal, with notes on its fishery in Bengal. In Proc. Nat. Inst. Sci. India, 20 (2),187-217

27. Pine, W.E., Pollock, K.H., Hightower, J.E. and Kwak, T.J. (2003). A review of tagging methods for estimation of fish population size and components of mortality. Fisheries 28 (10): 10-23. Doi: 10.1577/1548-8446(2003)28[10:AROTM F]2.0.CO.2

28. Rawat, V. S. and Nautiyal, P. (1996). Age and growth rate determination from pectoral and dorsal fin region scales of 
a hillstream teleost Barilius bendelisis (Hamilton) with a note on difference in their structure. Indian J Fish. 43(2): $171-178$.

29. Sarojini, K. K. (1957). Biology and fisheries of the grey mullets of Bengal I. Biology of Mugil parsia Hamilton with Notes on its Fishery in Bengal. Indian J. Fish. 4(1),160-207.

30. Seshappa, G. and Bhimachar, B.S. (1951). Age determination studies in fishes by scales with special reference to Malabar sole. Curr. Sci. 20: 260-262.

31. Singh, P.R., Dobriyal, A.K. and Singh, H. R. (2017). Study of age and growth of Labeo calbasu (Ham.) from the Ganga river system at Allahabad. J. Mountain Res. 12, 1-12.

32. Tandon, K. K. and Johal, M. S. (1996). Age and growth in freshwater fishes. Narendra Publishing House, New Delhi, 256.pp.

33. Tandon, K.K., Johal, M.S. and Kukreja, T. (1993). Mor- phometry, age and growth of silver carp. H. molitrix (Vol.) from Gobinsagar reservoir, Himachal Pradesh, India. Res. Bulletin of the Panjab Univ. 43: 117-130.

34. Uniyal, S.P., Dobriyal, A.K. and Joshi, H.K. (2005). Ageing biology and related growth statistics of a freshwater fish Tor chelynoides (Pisces: Cyprinadae) from Garhwal Himalaya India. Indian. J. Env. And Ecoplan. 10 (2), 273-283.

35. Van Oosten, J. (1937). The age, growth, and sex ratio of the Lake Superior longjaw, Leucichthys zenithicus (Jordan and Evermann). Papers of the Michigan Academy of Science, Arts, and Letters, 22, 691-711.

36. Vasudevappa, C. and James, P. S. B. R. (1988). Age and Growth of the Marine Catfish Tachysurus dussumieri (Val.) along the Dakshina Kannada Coast. In The First Indian Fisheries Forum. Proceedings (pp. 225-228). Asian Fisheries Society, Indian Branch. 